\title{
HYDRAULIC LOADER CRANE - OPERATOR WORKPLACE RISK ASSESSMENT
}

\author{
Atila Zelić ${ }^{1}$, Dragan Živanić ${ }^{1}$, Nikola Ilanković ${ }^{1}$, Mirko Katona ${ }^{1}$, \\ Kristina Jakimovska ${ }^{2}$, Anita Vasileva ${ }^{2}$, Nataša Antić ${ }^{3}$ \\ ${ }^{1}$ Faculty of Technical Sciences, University of Novi Sad, \\ Trg Dositeja Obradovića 6, 21000 Novi Sad, Republic of Serbia \\ ${ }^{2}$ Faculty of Mechanical Engineering, "Ss. Cyril and Methodius" University in Skopje, \\ P.O. Box 464, MK-1001Skopje, Republic of North Macedonia \\ ${ }^{3}$ ASIP Prevent, \\ Privrednikova 8a, 21000 Novi Sad, Republic of Serbia \\ ilankovic@uns.ac.rs
}

\begin{abstract}
A b s t r a c t: The aim of this paper is to assess the risk to health and safety at work while working with a hydraulic crane mounted on a truck. After the risk assessment, appropriate preventive measures for healthy and safety of work are prescribed, together with a short manual on health and safety at work. The expert finding of the hydraulic loader crane was processed according to the Ordinance on the Manner and Procedure of Risk Assessment at the Workplace and in the Work Environment (Official Gazette of Republic of Serbia, no. 114/2014 and 102/2015).
\end{abstract}

Key words: loader cranes; health and safety at work; risk assessment

\section{ХИДРАУЛИЧНА УТОВАРУВАЧКА ДИГАЛКА - ПРОЦЕНА НА РИЗИКОТ НА РАБОТАТА НА ОПЕРАTOPOT}

А п с т р а к т: Целта на овој труд е да се направи процена на ризикот за здравјето и безбедноста при работа со хидраулична дигалка поставена на камион. По извршената процена на ризикот, за да се овозможи безбедна работа, се пропишуваат соодветни превентивни мерки, заедно со краток издвоен прирачник за безбедност и здравје при работа. Стручниот наод за хидраулична дигалката поставена на камион е обработен според Правилникот за начинот и постапка при процена на ризик на работно место и во работна средина (Службен весник на Република Србија бр. 114/2014 и 102/2015).

Клучни зборови: утоварувачка дигалка; здравје и безбедност при работа; процена на ризик

\section{INTRODUCTION}

A hydraulic loader crane (Figure 1) is a crane installed on a truck of the appropriate chassis, for the purpose of loading and unloading of that vehicle.

Loader crane is mostly present in construction and communal works, maintenance works, facade and electrical works, etc.

The aim of this paper is to address the topic of risk assessment for safety and health at work when working with a loader crane, as well as inspection and verification of the same, with the formation of expert findings on safe use [1].

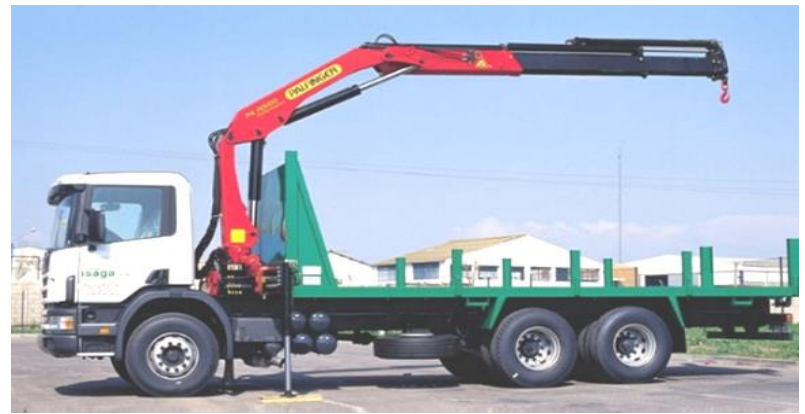

Fig. 1. Loader crane with hook 


\section{OVERVIEWS OF APPLICABLE REGULATIONS}

When it comes to operation, as well as health safety when working with a hydraulic loader crane, the following standards are relevant:

- ISO 15442:2012, [2];

- ISO 21308-5:2014, [3];

- BS 7121-4:2010, [4].

Priority in work is safety and health at work, i.e. ISO 15442: 2012, standard type C. The standard refers to minimum requirements related to the design, calculation, inspection and checking of hydraulic cranes and their supports on the chassis or fixed surface.

Standard ISO 21308-5: 2014 refers to the installation of a loading crane on a truck, the appropriate coding system and coordinate systems of structural parts, as well as their transformation into an appropriate system for convenient assembly of structural parts.

British standard BS 7121-4: 2010 also applies to occupational safety and health requirements.

\section{MAJOR SIGNIFICANT HAZARDS RELEVANT TO LOADER CRANE}

Annex A of ISO 15442:2012 provides a list of major hazards, as well as situations and events that may lead to risks to the health and safety of employees when working with a hydraulic loader crane (Table 1).

Table 1

\section{List of significant hazards [2]}

\begin{tabular}{l}
\hline \hline Hazards \\
Mechanical hazards related to inadequate mechanical strength \\
of the crane and its parts (crushing, shear, entanglement, \\
impact, puncture, loss of stability, etc.). \\
Electrical hazards (direct contact, indirect contact, thermal \\
radiation, etc.). \\
Thermal hazards, which cause burns and damage to health. \\
Dangers caused by noise. \\
Vibration hazards. \\
Hazards generated by materials and substances processed or \\
used by the machinery. \\
Dangers caused by neglect of ergonomic principles in \\
machinery design. \\
Unexpected start, unexpected speed. \\
Hazards caused by missing and/or incorrectly positioned \\
safety related measures/means. \\
Assembly errors. \\
Loss of stability / overturning of the machine.
\end{tabular}

\section{RISK ASSESSMENT FOR SAFETY AND HEALTH AT WORK WITH A HYDRAULIC LOADER CRANE}

The Ordinance on the Manner and Procedure of Risk Assessment at the Workplace and in the Work Environment [8], determines the manner and procedure of risk assessment of injuries at work or damage to health, or illness of the employee at work and in the work environment, as well as their elimination, which the employer regulates with the Risk Assessment Act. Risk assessment is performed for each identified hazard or harmfulness, by comparing it with the permitted values in the relevant occupational safety and health regulations, technical regulations, standards and recommendations. If, after the applied measures in the field of safety and health at work, the workplace still represents a risk, then the Risk Assessment Act declares the workplace as a workplace with increased risk, for which risk assessors must explain the dangers and harms of the workplace because of which the workplace is considered as a place with increased risk [5].

\section{a) Risk assessment act}

The two basic laws on the basis of which the Risk Assessment Act is issued are the Law on Safety and Health at Work [6] and the Ordinance on the Manner and Procedure of Risk Assessment at the Workplace and in the Work Environment [8].

The act on risk assessment consists of the described work processes of the appropriate workplace for each workplace, with an assessment of the risk of injuries or diseases in a given workplace and measures to eliminate or reduce risks in order to improve safety and health at work. The act is subject to complete amendment after each collective injury at work with fatal consequences, and is subject to partial amendments in the case of:

- fatal and serious injuries at work;

- any new hazards or harms (changes in risk levels);

- when measures identified to prevent, eliminate or reduce risks are not appropriate;

- when the assessment is based on outdated data;

- when there is a possibility and a way to improve (supplement the risk assessment). 


\section{b) Risk assessment methods}

According to [9], depending on the type of data they use, risk assessment methods can be: qualitative, quantitative and combined, i.e. semi-quantitative. They are divided into methods for estimating probabilities, which aim to identify and quantify areas of potential risk, and methods for assessing consequences, which aim to assess negative consequences, their effects and describe potential protection measures to eliminate these effects.

Qualitative methods use qualitative data; thus, the evaluation result is obtained as a qualitative quantity. Also, qualitative methods assess the application and compliance with the criteria defined by standards, laws, regulations and norms.

Quantitative methods use quantitative data and imply knowledge of the probability of an adverse event, which is reached on the basis of historical data, application of analytical techniques or expert assessments. It is also necessary to know the quantitative values of the expected consequences of the realization of this event. The quantitative measure of risk is most often determined as the product of the values of the stated quantities.

Semi-quantitative methods are based on expert judgments. When it is not possible to estimate the probability of rare events, as well as the magnitude of consequences (which may be different for different conditions), these magnitudes are estimated and ranked on the basis of probability and consequence scales, which are usually determined as a product or sum of probability measures and potential effects.

\section{c) Kinney method of risk assessment}

According to Kinney's risk assessment method, risk $R$ is determined using the form:

$$
R=V \times P \times U
$$

where $V$ denotes the probability of occurrence of the event, $P$ denotes the consequences, i.e. the severity of a possible injury or illness, while $U$ represents the frequency of exposure to events (i.e. hazards and / or harms).

\section{d) Workplace risk assessment for hydraulic loader crane operator}

When working with a hydraulic loader crane, the occurrence of mechanical hazards is primarily possible in the form of: jamming, impact, collapse; loss of crane stability due to inadequate substrate and unsafe installation of stabilizers; injury to employees due to the discharge of working fluid under high pressure from the hydraulic system; slipping, tripping and falling due to hydraulic oil leaks, etc. Dangers also occur during transport to the workplace, such as hitting parts of the traffic infrastructure, due to inadequate stacking of the loader crane. There are also dangers during the inadequate position of the operator (during which there is no complete visual inspection of the manipulation space), as well with space restrictions. All this can lead to inadequate performance of the work task and additional psychological burden on the operator. It should not be forgotten about the possibility of overturning the crane due to uncontrolled exceeding of the moment of stability, uncontrolled starting volume or unexpected movement of the load, as well as problems due to the choice of inadequate gripping means and equipment for tying / hanging loads.

The dangers that appear in connection with the characteristics of the workplace refer to the conditions of the work surface during different weather conditions, which can lead to inadequate installation of work equipment, as well as slipping and falling of workers on slippery surfaces due to snow and rain. Also, dangers can occur due to storms and lightning strikes. Electrical hazards, i.e. hazards arising from the use of electricity, occur in the form of hazards from direct contact with parts of electrical installation (such as control devices or overhead power lines), in the case of damaged installations, improperly performed installations, inappropriate equipment, then the dangers of thermal effects developed by electrical equipment and installations such as overheating, sparks and fires. Electrical hazards also occur during transport, in the case of inadequate stacking of the crane on the cargo space of the vehicle, during which the overhead power lines break.

There are also hazards that occur in the process of work such as damage to health when working at high or low temperatures, high or low humidity, higher airflow speed, work outdoors during exposure to IR and UV radiation, as well as noise that occurs during work and due to work performed in the immediate vicinity and harmfulness in the form of dust that occurs due to working conditions on dusty surfaces or with materials that produce dust. Harms resulting from psychological and psychophysiological efforts that are causally related to the workplace and jobs such as non-physiological body position, i.e. prolonged standing while operating a hydraulic loader crane or prolonged sitting during 
transport to the workplace, as well as responsibility in receiving and transmitting information and using appropriate knowledge and skills. In addition, the possibility of overtime often occurs.

By assessing the risk by the Kinney method, it was concluded that the position of the operator of a hydraulic loader crane is not a workplace with increased risk. However, a number of factors affect safety and health when operating a crane. Since the hydraulic loader crane is in most cases mounted on the truck, the change of work location is frequent and the conditions of the working surfaces are different. Often, the works take place near the shore, embankment or on a sloping terrain, which significantly affects the stability of the crane. Also, when working, one should not forget about the weather conditions, as well as the restrictions in urban areas. In such cases, the risk can be characterized as elevated, with possible catastrophic consequences for the lives of operators and workers in the vicinity of the crane.

\section{e) Recommended preventive measures against potential hazards}

According to potential hazards, preventive measures are prescribed such as:

- daily inspection of the parts of the hydraulic loader crane, increased caution when working;

- testing the substrate before starting work, i.e. before installing the stabilizer; installation of stabilizers according to the appropriate manufacturer's instructions;

- daily inspection of the hydraulic system and hydraulic hoses for mechanical damage;

- ban on the presence of unemployed persons;

- providing a signalman to make it easier for the operator to operate the crane;

- stacking the crane on the truck according to the manufacturer's instructions and not starting the transport before checking the adequate complexity of the crane;

- checking the correctness of the grounding of the truck and hydraulic loader crane and suspension of work during stormy weather;

- use of visual management, i.e. placing stickers on crane parts in order to remind employees of the dangers;

- use of personal protective equipment such as helmet, work suit, safety shoes, protective gloves, goggles, etc.

\section{INSPECTION AND CHECK OF HYDRAULIC LOADER CRANES}

The location of the test must be outside public places, such as roads, railways, factories and estates, which, in addition to interfering with the test, may also be endangered. The location where the test is performed must not be exposed to frequent and sudden weather changes (the test is never performed in rain, snow, fog, etc.). The test area must be fenced and marked with a sign prohibiting access by unauthorized persons. The test surface must be stable, sufficiently firm and level, with a maximum inclination of $\pm 0.5^{\circ}$. The space above the crane must be free and spacious, so that the crane can move freely.

According to the international standard, ISO 15442: 2012, the test is performed at a wind speed of less than $30 \mathrm{~km} / \mathrm{h}$, with the tire pressure prescribed by the manufacturer, and the crane itself should be installed and operated according to the manufacturer's instructions given in the operating instructions.

After a detailed inspection, a trial static and a dynamic test of the crane are performed, as well as a test of the vehicle's stability, at the critical position of the platform and the authoritative condition of the ground in relation to the slope of the terrain. The test is considered successful if no mechanical damage to the parts of the crane structure was noticed during the raised test load, i.e. there was no failure of the control / drive / safety systems or overturning of the crane itself.

Inspection is performed by a legal entity with a license to perform inspection of work equipment, which has the appropriate instruments and devices for inspection, listed with technical characteristics in the accepted methodology. When issuing the expert finding, the legal entity that performed the inspection shall enclose a copy of the license of that legal entity and the responsible person who signed the expert finding. The inspection report should be submitted and stored in a safe place, i.e. at the place of operation of the crane, and obligatorily in the cab of the vehicle.

Preventive inspections and checks of work equipment are performed:

- before the beginning of use, i.e. before giving for use to employees;

- after reconstruction or accident;

- before starting work at a new location, i.e. in the case of transferring a crane from one truck to another. 
Periodic inspections and checks of work equipment are performed within the period determined by technical regulations and standards or the manufacturer's instructions, and no later than 3 years from the date of the previous inspection and check [7].

\section{CONCLUSIONS}

Due to the widespread use of hydraulic loader cranes on trucks, it is necessary to perform certain assessments, inspections and checks, provided by law.

By considering the risk, realistic protection measures can be prescribed that will reduce that risk to a minimum. By reducing the risk, the number of injuries at work is reduced and the psychological well-being of the employee is achieved in the form of safe and secure performance of work and preservation of physical health. Although the risk assessment (in most cases in practice) does not identify the position of hydraulic loader crane operator as a high-risk position, a medical examination is recommended to determine the suitable functions of an employee working as a crane operator, such as vision, hearing, speed of reaction, communication etc. Medical examination and adequate training of the employee for safe and healthy work (at least once in three years), achieve the greatest possible safety when performing the work task, in addition to providing the correct equipment for work and personal protective equipment of the employee.

Acknowledgment: This research (paper) has been supported by the Ministry of Education, Science and Technological Development through project no. 451-03-9/2021-14/200156: "Innovative scientific and artistic research from the FTS (activity) domain".

\section{REFERENCES}

[1] Antić, N. (2019): Mere bezbednosti i zdravlja na radu sa hidrauličnim pretovarnim dizalicama, Bachelor thesis (in Serbian), Faculty of Technical Sciences, Novi Sad,

[2] International Standard: Cranes - Safety requirements for loader cranes, ISO 15442, Geneva (2012).

[3] International Standard: Road vehicles - Product data exchange between chassis and body work manufacturers (BEP) - Part 5: Coding of loader crane bodywork, ISO 21308-5, Geneva (2014).

[4] Standard: Code of practice for safe use of cranes - Part 4: Lorry loaders, BS 7121-4, London (2010).

[5] Jocić, N. (2008): Vodič za procenu i upravljanje rizikom: bezbednost i zdravlje na radu, Futura, Novi Sad.

[6] Zakon o bezbednosti i zdravlju na radu (,,Sl. glasnik RS“, br. 101/2005, 91/2015 i 113/2017-dr. zakon).

[7] Pravilnik o postupku pregleda i provere opreme za rad i ispitivanja uslova radne okoline (,, Sl. glasnik $R S$ “, br. 94/2006, 108/2006 - ispr., 114/2014 i 102/2015).

[8] Pravilnik o načinu i postupku procene rizika na radnom mestu i u radnoj okolini (,,Sl. glasnik RS“, br. 72/2006, 84/2006 - ispr., 30/2010 i 102/2015).

[9] Grozdanović, M., Stojiljković, E. (2013): Metode procene rizika, Fakultet zaštite na radu u Nišu, Niš. 
